\title{
Functional feminization of the Mexican snook (Centropomus poeyi) using 17ß-estradiol in the diet
}

\author{
Juan Manuel Vidal-López ${ }^{1}$, Wilfrido M. Contreras-Sánchez ${ }^{1}$, Arlette Hernández-Franyutti ${ }^{1}$ \\ María de Jesús Contreras-García ${ }^{1}$ \& María del Carmen Uribe-Aranzábal ${ }^{2}$ \\ ${ }^{1}$ Laboratorio de Acuicultura Tropical, División Académica de Ciencias Biológicas Tabasco \\ Universidad Juárez Autónoma de Tabasco, México \\ ${ }^{2}$ Animal Reproduction Biology Laboratory, Comparative Biology Department, Faculty of Sciences \\ Universidad Nacional Autónoma de México, Ciudad de México, México \\ Corresponding author: Wilfrido M. Contreras-Sánchez (contrerw@hotmail.com)
}

\begin{abstract}
The Mexican snook, Centropomus poeyi, supports an important fishery in southeastern Mexico. Due to its protandrous hermaphroditism, females may be especially sensitive to overfishing because they tend to be larger and selective removal has the potential to negatively affect natural populations, thus making urgent the need to contribute on management strategies for the species. The objective of this study was to produce batches of reproductive females at an early age and a small size by using $17 \beta$-estradiol (E2) in the diet. In two separate experiments, we fed fish $0,10,20,30,40,50$, or $60 \mathrm{mg}$ of $17 \beta$-estradiol per $\mathrm{kg}$ of food for 60 days during gonadal differentiation. Fish fed with 50 and $60 \mathrm{mg}$ of E2 per kg of food resulted in $100 \%$ feminization, while the control group ( $0 \mathrm{mg}$ of E2) was $100 \%$ male. Three years after feminization, sex-reversed fish remained female, producing oocytes and were capable of spawning, while fish in the control group were ripe males with running milt. E2-treated groups were significantly larger (weight and length) than the control groups for up to six months after treatment, but the difference was undetectable at 300 days post-treatment. Survival was high in all treatments $(100 \%)$. We obtained high percentages of functional females using dosages of 50 and $60 \mathrm{mg} \mathrm{kg}^{-1}$ of E2 for 60 days, with $80 \%$ of the induced fish spawning and producing fertilized eggs and larvae. The results obtained in this study provide opportunities for broodstock management and sex manipulation.
\end{abstract}

Keywords: Centropomus poeyi; sex-inversion; functional females; snook culture; aquaculture

\section{INTRODUCTION}

Several centropomid species support important recreational and commercial fisheries in the Gulf of Mexico (Tucker, 2003; Alvarez-Lajonchère \& Tsuzuki, 2008). Recent harvest rates in this region are lower than in the previous decade (FAO, 2011; Chávez-Caballero et al., 2014). In Mexico, snooks command high prices. In 2013, the reported landing of snooks in Mexico was 8,085 t, with $75 \%$ of the total catch from the Gulf of Mexico (SAGARPA, 2017). Unfortunately, all snook species captured are reported under the generic category of "snooks" (FAO, 2011). This broad labeling of landed species impedes the assessment of fisheries at the species level.

Centropomus poeyi is an endemic species that occurs only in watersheds located between the Mexican states of Tamaulipas and Campeche that discharge into the Gulf of Mexico (Chávez, 1961, 1963). Contrary to $C$. parallelus and C. undecimalis, the Mexican snook spends most of its life cycle in rivers and lagoons, migrating to the ocean only to spawn (Chávez, 1981). The Mexican snook is a piscivorous species, reaching a total length of up to $110 \mathrm{~cm}$ and a weight of $14 \mathrm{~kg}$, with females being significantly larger than males (LoranNúñez et al., 2012; Chávez-Caballero, 2014). Very little is known about the biology, ecology, or population status of the Mexican snook. While all snooks are considered protandric hermaphrodites (AlvarezLajonchère \& Tsuzuki, 2008), only C. undecimalis is documented as such (Taylor et al., 2000).

The potential for snook aquaculture has been highlighted, and specific studies have developed methods for culturing $C$. undecimalis and $C$. parallelus (Zarza et al., 2006; Lajonchère \& Tsuzuki, 2008; Cerqueira \& Tsuzuki, 2009; Yanes-Roca et al., 2009; Ibarra-Castro et al., 2011; Contreras-García, 2015). However, there are no experimental studies on the culture of $C$. poeyi in captivity. In our facilities, we have observed that $C$. poeyi has advantages over other 
centropomids (i.e., large size, high tolerance to handling, grow-out in a wide range of salinities, and fast growth). Broodstock management for C. poeyi is complicated because females range from five to ten $\mathrm{kg}$. This makes operations expensive, not to mention the risks associated with maintaining large fish captive. Therefore, this study aimed to produce batches of reproductive females at an early age and a small size through induced sex inversion using 17\%-estradiol in this hermaphroditic species. This natural estrogen has been frequently used in gonochoristic species; however, there are few studies on induced feminization in hermaphroditic fishes. In this study, we investigated the effect of different dosages of the steroid $17 \beta$-estradiol on the sex ratios, growth, reproductive viability, and survival of $C$. poeyi.

\section{MATERIALS AND METHODS}

\section{Broodstock and larvae production}

Wild-caught broodstock was maintained in $63 \mathrm{~m}^{3}$ circular plastic tanks (9 m diameter) with a daily $10 \%$ water exchange and natural photoperiod at the Marine Aquaculture Station, Biological Sciences Division, Juárez Autonomous University of Tabasco located in Jalapita, Centla, Tabasco (MAS-UJAT). In two separate spawning events, one mature female and two males (average weight $5.550 \pm 223$ and $3.000 \pm 68 \mathrm{~g}$, respectively) were induced using handmade cholesterol implants with $200 \mu \mathrm{g}$ per fish of LHRHa (Syndel, Western Chemical, USA) and placed in a fiberglass spawning tank (4 m diameter, $1 \mathrm{~m}$ depth). Spawning began after $27 \mathrm{~h}$; fertilized eggs were collected using a $400 \mu \mathrm{m}$ soft-mesh net. Embryos were placed in $500 \mathrm{~L}$ fiberglass tanks, and hatching started $44 \mathrm{~h}$ later. The yolk-sac larvae were maintained in these tanks with a daily $80 \%$ water exchange and continuous aeration. Salinity $(28.6 \pm 1.9 \mathrm{ppm})$, dissolved oxygen $(6.6 \pm 1.1 \mathrm{mg}$ $\left.\mathrm{L}^{-1}\right)$, and temperature $\left(27.1 \pm 2.5^{\circ} \mathrm{C}\right)$ were monitored daily. At 15 days post-hatching (dph), salinity was gradually lowered (5 ppm per day) until the fish were in fresh water. Tanks were filled with salt water and stocked with a mix of the green microalgae Tetraselmis chuii, T. suecica, and Nannochloropsis oculata (2$4 \times 10^{5}$ cells $\left.\mathrm{mL}^{-1}\right)$. Rotifer supplementation was initiated with Brachionus rotundiformis at 20 rotifers $\mathrm{mL}^{-1}$; at $11 \mathrm{dph}$, the density was decreased to 15 rotifers $\mathrm{mL}^{-1}$ and $B$. plicatilis was added at a density of 15 rotifers $\mathrm{mL}^{-1}$, making a total of 30 rotifers $\mathrm{mL}^{-1}$ until 22 dph. At $13 \mathrm{dph}$, Artemia nauplii were added to the mix at a rate of 30 ind $\mathrm{mL}^{-1}$, until $22 \mathrm{dph}$. Larvae were weaned onto commercial food (Gemma Wean ${ }^{\mathrm{TM}}$, Skretting; proximate composition: $62 \%$ protein, $14 \%$ lipid, $8 \%$ ash, $0.2 \%$ fiber) beginning at $20 \mathrm{dph}$ and continued for six months. After six months, fish were fed Europa ${ }^{\mathrm{TM}}$, (Skretting; proximate composition: 55\% protein, $15 \%$ lipid, $12 \%$ ash, $1.0 \%$ fiber, $8.5 \%$ moisture).

\section{Specimen procurement}

Two experiments were carried out at the Tropical Aquaculture Laboratory, Biological Sciences Academic Division, Juárez Autonomous University of Tabasco. Juveniles were obtained from induced spawnings in October 2013 and October 2014. Experimental juvenile fish (120 and 240 individuals) were randomly selected for experimental groups I and II, respectively. Juveniles were $340 \mathrm{dph}$ in experiment $\mathrm{I}$ and $227 \mathrm{dph}$ in experiment II. Pre-treatment gonadal condition was determined with conventional hematoxylin-eosin staining.

\section{Experimental design}

Separate experiments were carried out using a completely randomized design with one factor (E2 dose) to evaluate the feminizing effects of E2 in food. Each experiment consisted of four treatments that were run in triplicate. In the first experiment, we evaluated 40, 50, and $60 \mathrm{mg} \mathrm{E} 2 \mathrm{~kg}^{-1}$ of food. In the second experiment, we assessed the effects of 10,20 , and 30 mg E2 $\mathrm{kg}^{-1}$ of food. In both experiments, a control group (0 mg E2 $\mathrm{kg}^{-1}$ of food) was included. Ten juveniles were randomly placed in each experimental unit for the first experiment, with an initial average total length of $150.2 \pm 1.6 \mathrm{~mm}$, and a weight of $30.1 \pm 9.8 \mathrm{~g}$. For the second experiment, we used 20 juveniles per replicate, with an initial average total length of $73.7 \pm$ $4.5 \mathrm{~mm}$, and a weight of $2.8 \pm 0.4 \mathrm{~g}$. Both experiments were carried out in a closed recirculating system, consisting of twelve 2,000 L capacity circular tanks. All tanks were filled with non-chlorinated freshwater and kept under chemical and mechanical filtration during the experiment. The water was filtered over a homemade filter tank to remove residual E2 and sediments. This filter was built using a $200 \mathrm{~L}$ plastic tank (60 cm diameter, $90 \mathrm{~cm}$ height) containing three layers of filtering materials: a) $5 \mathrm{~kg}$ of granular activated charcoal (Silva et al., 2012) contained in a plastic mosquito mesh bag (1 mm mesh size); b) $10 \mathrm{~kg}$ of crushed oyster shells; and c) $10 \mathrm{~kg}$ of fine gravel. Water passed by gravity to a 5,000 L reservoir tank and recirculated into the fish tanks by using a $1.5 \mathrm{HP}$ suction pump equipped with a pressured sand filter (Jacuzzi L190, USA). Waste accumulated in the fish tanks was siphoned daily, and $30 \%$ of the water was replaced once a week. Replicates from the control group were maintained in similar tanks separated from the recirculating system. 


\section{Experimental diets}

In both experiments, we fed the fish with commercial marine-fish food Europa ${ }^{\circledR}$ (55\% protein) impregnated with the different dosages of E2. The protocol proposed by Popma \& Green (1990) was used to impregnate the food with $17 \beta$-estradiol, varying the dosages for each treatment. Briefly, the desired dose of E2 (SigmaAldrich Co., USA) was dissolved in $100 \mathrm{~mL} \mathrm{96 \%}$ ethanol and sprayed onto $1 \mathrm{~kg}$ of the powdered food. Ethanol was left to evaporate at ambient temperature in a dark room, and afterward, the food was stored refrigerated at $4{ }^{\circ} \mathrm{C}$. Food for the control groups was impregnated with $96 \%$ ethyl alcohol only. Fish were fed until apparent satiation at 8:00, 11:00, 14:00, and 17:00 h, during 60 days for both experiments.

\section{Water quality}

Dissolved oxygen, temperature, and $\mathrm{pH}$ were measured in both experiments. Dissolved oxygen (6.02 \pm 0.02 and $6.4 \pm 0.03 \mathrm{mg} \mathrm{L}^{-1}$ ) was measured with a YSI Model 55 oxygen meter (Yellow Springs, USA), and temperature $\left(30.2 \pm 0.14^{\circ} \mathrm{C}\right.$ and $\left.29.5 \pm 0.16^{\circ} \mathrm{C}\right)$ with a digital thermometer (YSI 55, USA). The $\mathrm{pH}(6.5 \pm 0.07$ and $7.1 \pm 0.09$ ) was measured using a $\mathrm{pH}$ meter (Denver Instrument UB-10, USA). We measured ammonia (0.1 \pm 0.01 and $\left.0.14 \pm 0.011 \mathrm{mg} \mathrm{L}^{-1}\right)$, nitrite $(0.01 \pm 0.01$ and $\left.0.012 \pm 0.013 \mathrm{mg} \mathrm{L}^{-1}\right)$, and nitrate $(0.5 \pm 0.03$ and $0.7 \pm$ $\left.0.04 \mathrm{mg} \mathrm{L}^{-1}\right)$ concentrations with a multiparameter meter (Hanna Instruments, HI 98311, USA) every week.

\section{Growth and survival assessment and histological analysis}

Once the E2 exposure period concluded, we carried out three samplings (30, 180, and 300 days post-treatment) using a similar procedure in both experiments. At the end of each treatment, and in the subsequent samplings, weight was determined with an analytical scale (Ohaus ${ }^{\circledR}$, USA), with an accuracy of $0.001 \mathrm{~g}$, and we measured total length with digital vernier calipers (Carbon fiber Composites Digital ${ }^{\circledR}$, USA), with an accuracy of $0.1 \mathrm{~mm}$. Measurements were made on all specimens in each treatment. Survival was evaluated by counting the fish from each experimental unit at the end of the experiments. Subsamples were randomly taken from each replicate at each sampling time $(\mathrm{n}=3,2$, and 1) totaling 18 per treatment in experiment I and 27 for experiment II $(\mathrm{n}=3,3$, and 3$)$ to determine sex ratio. Twelve (experiment I) and 33 (experiment II) fish per treatment remained after assessment of sex ratios for viability trials. Sampled fish were sacrificed with an overdose of tricaine methanesulphonate (MS-222; $1 \mathrm{~g}$ $\left.\mathrm{L}^{-1}\right)$. Afterward, the fish were dissected, and the gonads were removed, fixed for $24 \mathrm{~h}$ in Bouin's solution, and then maintained in 50\% ethyl alcohol. Samples were processed and stained with hematoxylin-eosin (H-E) (Aguilar et al., 1996). Slides were examined with a compound microscope (Zeiss ${ }^{\circledR}$, Germany) with 10x and 40x objectives. Sex was assigned histologically using the criteria for $C$. undecimalis adults as reported by Grier \& Taylor (1998) and Grier (2000); for juveniles of the same species as reported by Huber et al. (2014); and as reported for other teleost fish species by multiple studies (Nakamura et al., 1998; Devlin \& Nagahama, 2002; Strüssmann \& Nakamura, 2002; Meijide et al., 2005).

\section{Female maturation and viability}

All remaining fish from treatments with 50 and $60 \mathrm{mg}$ $\mathrm{kg}^{-1}$ (24) and the control groups (45) were implanted with a PIT tag (Avid Identification Systems, Inc., USA) in the body cavity and moved to the marine station (MAS-UJAT) for grow-out and spawning trials. At four years of age, during the spawning season (JulySeptember), the fish kept for reproduction trials were anesthetized with clove oil $\left(0.015 \mathrm{~mL} \mathrm{~L}^{-1}\right)$ and checked for maturity. Each remaining females and males were checked for maturity by taking oocytes or sperm from the genital pore with a polyethylene cannula. The fish were declared as mature when females presented vitellogenic oocytes and males if running milt was present. Oocyte diameter and maturity stage were determined for every fish. Five females (449.46 \pm $161.33 \mathrm{~g}$ and $37.17 \pm 4.47 \mathrm{~cm}$ ) were selected for viability trials based on having oocytes larger than 150 $\mu \mathrm{m}$ in diameter. Ten males $(317.36 \pm 11.36 \mathrm{~g}$ and 34.50 $\pm 3.75 \mathrm{~cm}$ ) with running milt were also selected. All selected fish were implanted with LHRH-a $\left(150 \mu \mathrm{g} \mathrm{kg}^{-1}\right)$ handmade cholesterol-cellulose implants in the body cavity, near the pelvic fin. Fish were then placed in a $12.5 \mathrm{~m}^{3}$ tank where salinity (30.67 \pm 1.67$)$, temperature $\left(29.96 \pm 0.86^{\circ} \mathrm{C}\right)$, dissolved oxygen $\left(5.98 \pm 0.43 \mathrm{mg} \mathrm{L}^{-1}\right)$, and $\mathrm{pH}(8.46 \pm 0.22)$ were monitored three times a day. Five spawning trials were conducted using one female and two males per trial.

\section{Statistical analysis}

The effects of different E2 treatments on the sex ratio, growth (total length and weight), and survival rate, were analyzed using one-way ANOVA. Data expressed as percentages were arcsine-transformed before the ANOVA; however, sex ratios are reported as percentages. If the ANOVA revealed significant differences, Tukey's post-hoc test was performed. Normality (Shapiro-Wilk test) and variance homogeneity (Levene's test) were previously tested in all cases. All statistical analyses were performed using the Statgraphics Centurion ${ }^{\circledR}$ program, v XVI (level of significance $\alpha<0.05$ ). 


\section{RESULTS}

\section{Feminization}

A significantly higher percentage of females were obtained in the E2 treatments $(P<0.001)$. Induced females exhibited a normal pattern of ovarian development (Fig. 1) while the control groups consisted exclusively of males (Fig. 2). The fish fed with 50 and $60 \mathrm{mg}$ of $\mathrm{E} 2 \mathrm{~kg}^{-1}$ of food consistently produced $100 \%$ females, in the three consecutive samplings. Fish fed with $40 \mathrm{mg}$ of E2 $\mathrm{kg}^{-1}$ of food produced significantly fewer $(77.8 \% \pm 5.6 \mathrm{SE}$, standard error $)$ females $(P<$ 0.05 ) compared to fish fed the highest dosages (Fig. 3). In the control group, $100 \%$ of males were consistently obtained at all sampling times, with different phases of spermatogenesis (Fig. 4).

In experiment II, a significant proportion of females were obtained in each treatment $(P<0.05)$. As in experiment $\mathrm{I}$, the control group was all males, while fish fed the three E2 diets resulted in 37 to $63 \%$ females (Fig. 5). Fish fed $10 \mathrm{mg} \mathrm{E} 2 \mathrm{~kg}^{-1}$ of food resulted in only $37.0 \pm 6.4 \%$ females, a significantly lower percentage $(P<0.05)$ compared to those fed 20 and $30 \mathrm{mg} \mathrm{E} 2 \mathrm{~kg}^{-1}$ of food (59.7 and $63.3 \%$ females $\pm 6.4 \mathrm{SE}$ ). Histological analysis confirmed that females developed ovaries with evidence of primary growth oocytes (Fig. $6)$.

\section{Growth and survival}

In the experiment I, the total length and final weight in all three samplings differed significantly among treatments $(P<0.05)$. At 30 days post-treatment, the longest $(187.20 \pm 12.0 \mathrm{~mm})$ and the heaviest $(55.46 \pm$ $3.50 \mathrm{~g}$ ) fish were obtained from the $60 \mathrm{mg} \mathrm{E} 2 \mathrm{~kg}^{-1}$ treatment groups. Fish in the control group had the least growth $(164.90 \pm 11.7 \mathrm{~mm}$ and $35.93 \pm 2.96 \mathrm{~g})$. After 180 days post-treatment, the highest growth rates were found in the $60 \mathrm{mg} \mathrm{E} 2 \mathrm{~kg}^{-1}$ of food treatment, and the lowest growth rates occurred in the control group. At 300 days, post-treatment, no significant statistical differences $(P>0.05)$ were found in total length and weight (Table 1). In experiment II, the total length and final weight for all three samplings differed significantly among the treatments $(P<0.05)$. At 30 days, the fastest growth in total length was observed in the treatment with $20 \mathrm{mg} \mathrm{E} 2 \mathrm{~kg}^{-1}$ of food $(187.20 \pm 12.0$ $\mathrm{mm}$ ), and the greatest increase in weight was observed in the $30 \mathrm{mg} \mathrm{E} 2 \mathrm{~kg}^{-1}$ group $(55.46 \pm 3.50 \mathrm{~g})$. The least growth was observed in the control group. At 180 days, fish treated with $30 \mathrm{mg} \mathrm{E} 2 \mathrm{~kg}^{-1}$ of food had the highest growth rates $(215.57 \pm 19.20 \mathrm{~mm}$ of total length and $58.80 \pm 1.00 \mathrm{~g}$ of weight). Finally, at 300 days, significant differences persisted (Table 2). Survival was
$100 \%$ in all treatments, for both experiments (Tables 12).

\section{Sexual maturation and reproductive viability}

All fish treated with 50 and $60 \mu \mathrm{g} \mathrm{E} 2 \mathrm{~kg}^{-1}$ of food (experiment I) that were kept for sexual maturity assessments and viability tests were females producing oocytes (30 to $300 \mu \mathrm{m}$ in diameter); while fish (45) from the control group were all males with running milt. Five of the females obtained through sex inversion had oocytes larger than $150 \mu \mathrm{m}$ and were selected for induced spawning trials. Four of these females (80\%) spawned, and produced fertilized eggs and larvae. An average of $386,425 \pm 43,922$ eggs was produced per female. The fertilization rate averaged $76.4 \pm 14.71 \%$. The average number of larvae obtained in each spawning trial was $243,621 \pm 3,813$.

\section{DISCUSSION}

Results indicate that strongly skewed populations with functional females can be obtained from immature males after feminization using 50 or $60 \mathrm{mg} \mathrm{E} 2 \mathrm{~kg}^{-1}$ of food, for 60 days. Females obtained through sex inversion are fertile organisms of small size that can be induced to spawn and produce larvae. Induction of sex change in teleost fish is possible because germ cells are bipotential and their sensitivity to exogenous hormones allow disruption of the natural biochemical processes that govern sex differentiation, overriding normal developmental patterns even after gonadal differentiation has taken place (Devlin \& Nagahama, 2002; Strüssmann \& Nakamura, 2002). This plasticity in sexual development is the key to sexual manipulation in fish and can be effective even in the presence of genetic material for sex determination (Yamamoto, 1969; Goudie et al., 1983; Pandian \& Sheela, 1995; Piferrer, 2001; Devlin \& Nahagama, 2002). Such manipulation of gonadal development by steroid induction has been used to obtain single-sex populations (Baroiller et al., 1999; Devlin \& Nahagama, 2002; Omoto et al., 2002; Strüssmann \& Nakamura, 2002), aiming to increase productivity by avoiding unwanted reproduction, favor the sex with fastest growth, and produce groups of females with enhanced production of eggs (Beardmore et al., 2001; Piferrer, 2001; Devlin \& Nahagama, 2002; Frisch, 2004).

In an extensive review, Piferrer (2001) cites over 50 species in which feminization has been carried out, with salmonids and cichlids been the most representative groups. These studies have examined the use of different steroids and dosages, lengths of steroid treatment and gonad development. With centropomids, 


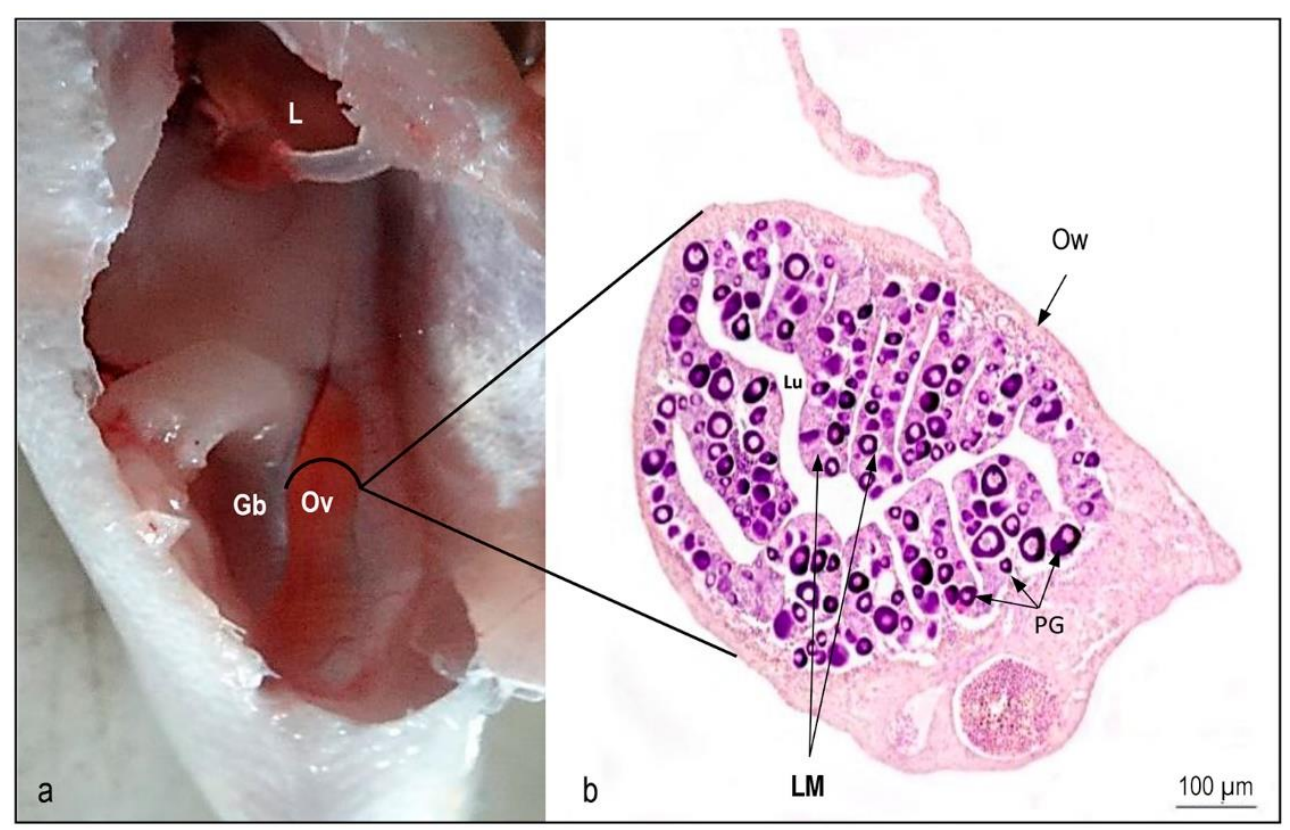

Figure 1. Characteristics of Centropomus poeyi ovaries. a) Anatomical position and macroscopic appearance of ovaries from females obtained after E2 treatment, b) microscopic view of a complete transverse section of an ovary. Liver (L); gas bladder $(\mathrm{Gb})$; ovary $(\mathrm{Ov})$; ovary wall $(\mathrm{Ow})$; lamellae $(\mathrm{LM})$; primary growth oocytes (PG); lumen (Lu). Hematoxylin and eosin.

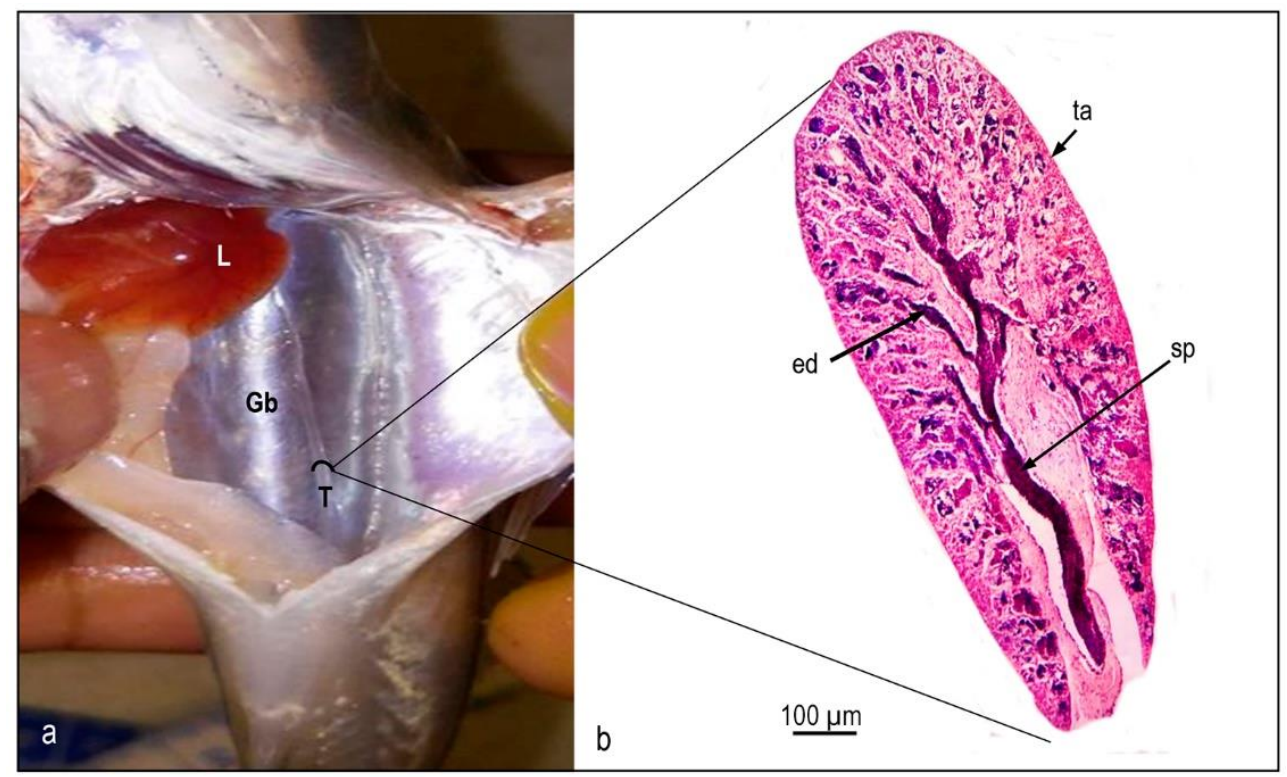

Figure 2. Characteristics of Centropomus poeyi testes. a) Anatomical position and macroscopic appearance of the testes from control group males, b) microscopic view of a complete transverse section of a testis. Liver (L); gas bladder (Gb); testis (T); efferent duct (ed); sperm (sp); tunica albuginea (ta). Hematoxylin and eosin.

specifically $C$. undecimalis and $C$. parallelus, positive results were obtained when the steroid was supplied using food or implants, obtaining high percentages of feminization in both species (Vidal-López et al., 2012; Carvalho et al., 2014; Passini et al., 2016).
Histological evidence indicated that the fish used had begun to differentiate into males, supported with the appearance of the efferent duct, and an increase in the number and size of the primordial germinal cells. Therefore, we conclude that sex inversion was effective. 


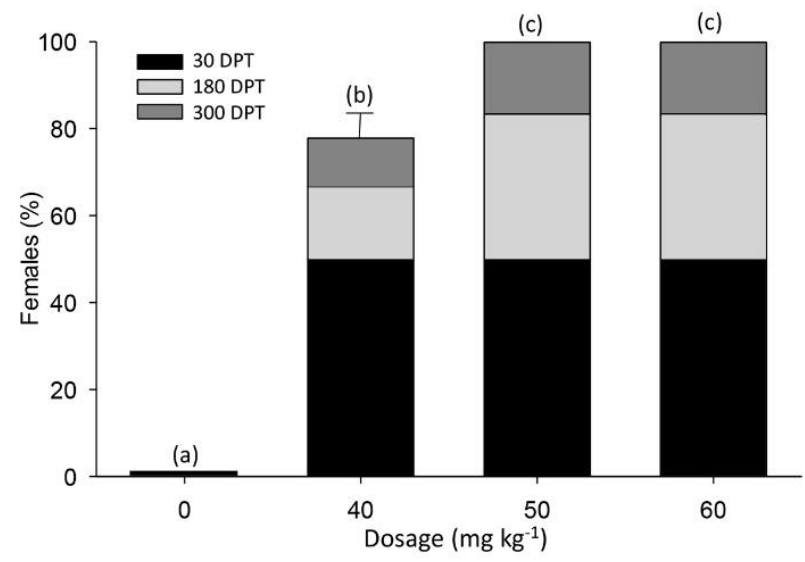

Figure 3. Average cumulative percent ( \pm standard error) of Centropomus poeyi females obtained for the control and treatments fed high dosages of E2 in experiment I. Different color bars indicate percent females at each sampling time for a particular treatment. Different letters indicate statistically significant differences between treatments (ANOVA, $P<0.05$ ). n = 18 for each treatment. DPT: Days post-treatment.

Since the terms "sex inversion" and "sex reversal" frequently appear interchangeably in the literature, we considered it necessary to reexamine this topic in the light of sex manipulation in hermaphroditic species: initially, Nakamura \& Takahashi (1973) described sex reversal for gonochoristic species as the time when fish gonads are sexually undifferentiated but are susceptible to the action of exogenous steroids. Chan \& Yeung (1983) further discussed this, defining the term as the transformation of an individual fish from one sex to another. Green et al. (1997) attempted to differentiate induction of sex change, in undifferentiated and differentiated fish, by arguing that the term "sex inversion" is defined as the process where the undifferentiated gonad is directed to a particular sex, and "sex reversal" as the induction of a differentiated gonad to become that of the opposite sex. In the case of hermaphroditic species, both terms stand, since sex change can be induced during both stages of gonadal development, supported by the successful sex inversion of juvenile sea bream, Sparus aurata (Condeça \& Canario, 1999); common snook, C. undecimalis (VidalLópez et al., 2012; Carvalho et al., 2014) and fat snook, C. parallelus (Carvalho et al., 2014). While sex reversal has been documented for adult blue-spotted grouper, Epinephelus fario (Kuo et al., 1988), black porgy, Acanthopagrus schlegeli (Chang, et al., 1994, 1995), black sea bass, Centropristis striata L. (Benton \& Berlinsky, 2006), three-spot wrasse, Halichoeres trimaculatus (Nozu, et al., 2009), and adult fat snook (Passini et al., 2016). Contrary to this, Piferrer (2001) mentioned that for some gonochoristic species, once the sexual differentiation process is advanced, or the gonads are mature, it is more difficult to change the sex and may become impossible in some cases.

An important aspect of this type of study is the identification of an effective dose and an optimal time of steroid application, with the purpose of optimizing resources. We did not assess different times for steroid application, but the results of Vidal-López et al. (2012) in $C$. undecimalis were considered, suggesting that more than 21 days of exposure produced high rates of feminization. Nevertheless, in the present study, the assessment of different dosages was necessary, and we determined that dosages of 50 and $60 \mathrm{mg} \mathrm{E} 2 \mathrm{~kg}^{-1}$ of food were highly efficient without compromising survival. The dose required for the feminization of fish species is highly variable. Piferrer (2001) detailed successful feminization using estradiol in food with dosages ranging from $1 \mathrm{mg} \mathrm{kg}^{-1}$ in Mugil cephalus to 400

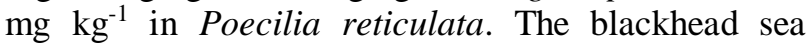
bream, Acanthopagrus schlegelii, can be feminized using as low as $4 \mathrm{mg} \mathrm{kg}^{-1}$ of estradiol in the diet;

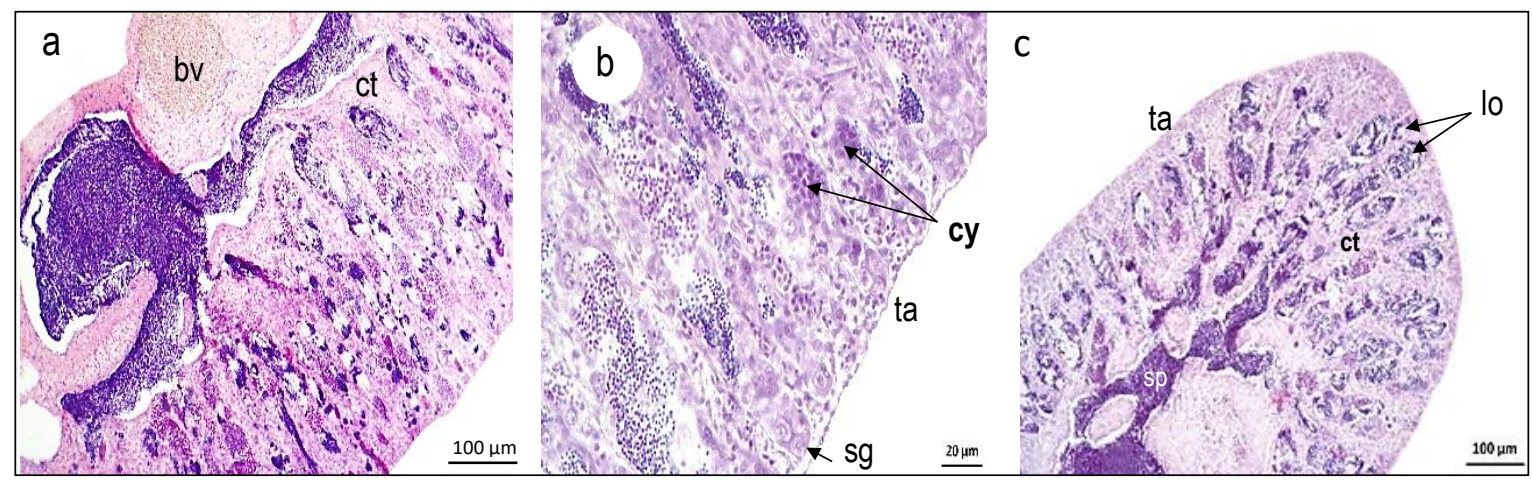

Figure 4. Unrestricted lobular testes from Centropomus poeyi obtained from males of the control group. a) Details from the transverse section of testes sampled at 60, b) 180 and c) 300 days post-treatment (100x; 40x and 10x, respectively). Efferent duct (ed); cysts (cy); spermatogonia (sg); sperm (sp); tunica albuginea (ta); blood vessels (bv); connective tissue (ct); lobules (lo). Hematoxylin and eosin. 


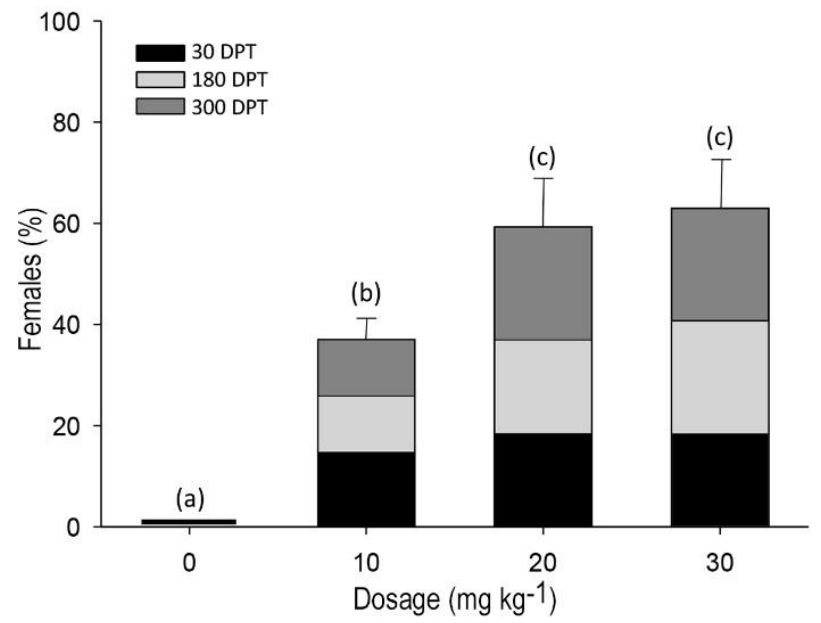

Figure 5. Average cumulative percent ( \pm standard error) of Centropomus. poeyi females obtained in the experiment with $0,10,20$ and $30 \mathrm{mg}$ of E2 per $\mathrm{kg}$ of food. Different color bars indicate the percent of females at each sampling time for a particular treatment. Different letters indicate statistically significant differences between treatments (ANOVA, $P<0.05$ ). $\mathrm{n}=27$ for each treatment. DPT: Days post-treatment.

however, this protocol requires five months of treatment (Chang \& Lee, 1992). Strüssmann et al. (1996) obtained $100 \%$ females using 77 days of treatment with food impregnated with E2 at dosages of $20 \mathrm{mg} \mathrm{kg}^{-1}$ of food in the pejerrey, Odontesthes bonariensis. In centropomids, Vidal-López et al. (2012) presented histological evidence of significant feminization of the gonads in $C$. undecimalis by feeding $50 \mathrm{mg} \mathrm{E} 2 \mathrm{~kg}^{-1}$ of food for 21 to 42 days. However, the reproductive viability of the females was not demonstrated. Likewise, complete sexual inversion was attained in adult males of this species, using implants at dosages ranging from 0.5 to $1.0 \mathrm{mg} \mathrm{E} 2 \mathrm{~kg}^{-1}$ of fish (Passini et al., 2016). In a closely related but smaller species ( $C$. parallelus), Carvalho et al. (2014) produced up to $100 \%$ females when $25 \mathrm{mg} \mathrm{E} 2 \mathrm{~kg}^{-1}$ of food was provided for 45 days. Unfortunately, in all cases, reproductive viability was not reported.

One important contribution of this investigation was the assessment of the treated fish at three different periods (30, 80, and 100 days post-treatment), to observe morphological and structural changes in the development of the gonad. Based on the histological analyses of 93 sex-inversed females, no abnormal morphological or structural changes were observed during gonad development, indicating that the ovaries followed a "normal pattern" of development. Furthermore, the high survival rate of the fish kept for viability tests and the successful production of larvae support the well-being of the females. However, it is important to mention that some studies have reported that exposure to estrogenic compounds can induce abnormalities in behavior and the structure and morphology of the gonads (intersex organisms and structural anomalies) and other organs. For example, Islinger et al. (2003) reported ultrastructural changes in the livers and testes of zebrafish, Danio rerio; Flynn \& Benfey (2007) found mottled livers, swollen kidneys, and reduced gonad size in shortnose sturgeons, Acipenser brevirostrum; and Hendry et al. (2003) detailed irreversible injuries in Atlantic halibut, Hippoglossus hippoglossus L. including spinal deformities and high mortality rates, after E2 treatment. One possible explanation of these anomalies in growth and development may be related to altered interactions between sex steroids, growth hormone, and thyroid hormones (De Jesus et al., 1992; Lin et al., 1995) produced by the exogenous exposure to E2.

Growth was enhanced when juveniles were fed a diet containing $17 \beta$-estradiol. The highest dose of E2

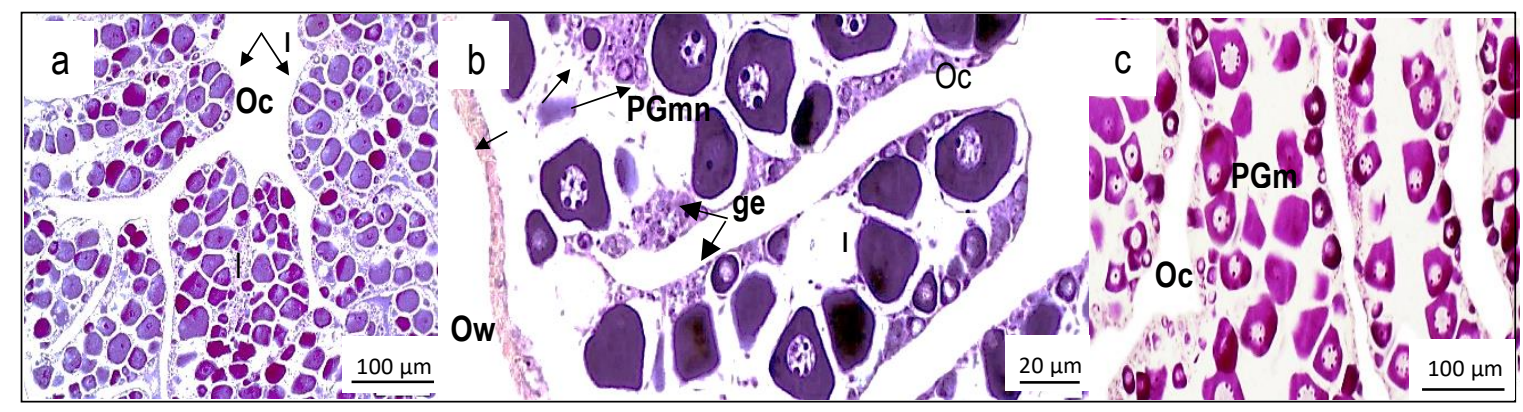

Figure 6. Cystovarian ovaries from Centropomus. poeyi obtained from E2-treated organisms. a) Details from transverse cuts of ovaries sampled at 60, b) 180 and c) 300 days post-treatment (100x; 40x and 10x, respectively). Ovarian cavity (Oc); lamellae (1); primary growth oocyte during multiple nucleoli stage (PGmn); germinal epithelium (ge); ovarian wall (Ow). Hematoxylin and eosin. 
Table 1. Average values for weight and total length $( \pm$ SE) of Centropomus. poeyi juveniles treated with $0,40,50$ and 60 $\mathrm{mg}$ of $\mathrm{E} 2$ per $\mathrm{kg}$ of food $(\mathrm{n}=30)$ at different days post-treatment $(\mathrm{DPT})$. Survival was $100 \%$ in all treatments. Different letters indicate statistically significant differences $(P<0.05)$.

\begin{tabular}{ccccc}
\hline $\begin{array}{c}\text { Treatment } \\
\text { E2 }\left(\mathrm{mg} \mathrm{kg}^{-1}\right)\end{array}$ & $\begin{array}{c}\text { 0 DPT } \\
\text { mean }( \pm \text { SE })\end{array}$ & $\begin{array}{c}\text { 30 DPT } \\
\text { mean }( \pm \text { SE })\end{array}$ & $\begin{array}{c}\text { 180 DPT } \\
\text { mean }( \pm \text { SE })\end{array}$ & $\begin{array}{c}\text { 300 DPT } \\
\text { mean }( \pm \text { SE })\end{array}$ \\
\hline 0 & $33.12 \mathrm{~g} \pm 1.43 \mathrm{~g}^{\mathrm{a}}$ & $35.93 \pm 0.96 \mathrm{~g}^{\mathrm{a}}$ & $49.18 \pm 0.35 \mathrm{~g}^{\mathrm{a}}$ & $175.03 \pm 1.93 \mathrm{~g}^{\mathrm{a}}$ \\
& $158.97 \pm 2.53 \mathrm{~mm}^{\mathrm{a}}$ & $164.90 \pm 1.22 \mathrm{~mm}^{\mathrm{a}}$ & $173.10 \pm 1.66 \mathrm{~mm}^{\mathrm{a}}$ & $270.60 \pm 1.43 \mathrm{~mm}^{\mathrm{a}}$ \\
\hline 40 & $43.98 \pm 2.25 \mathrm{~g}^{\mathrm{ab}}$ & $50.34 \pm 1.93 \mathrm{~g}^{\mathrm{ab}}$ & $57.48 \pm 0.30 \mathrm{~g}^{\mathrm{b}}$ & $179.97 \pm 1.56 \mathrm{~g}^{\mathrm{a}}$ \\
& $174.27 \pm 3.09 \mathrm{~mm}^{\mathrm{b}}$ & $183.60 \pm 2.34 \mathrm{~mm}^{\mathrm{b}}$ & $198.30 \pm 0.54 \mathrm{~mm}^{\mathrm{b}}$ & $272.00 \pm 1.67 \mathrm{~mm}^{\mathrm{a}}$ \\
\hline 50 & $46.66 \pm 1.75 \mathrm{~g}^{\mathrm{b}}$ & $54.89 \pm 2.33 \mathrm{~g}^{\mathrm{b}}$ & $57.93 \pm 0.33 \mathrm{~g}^{\mathrm{b}}$ & $178.10 \pm 0.97 \mathrm{~g}^{\mathrm{a}}$ \\
& $175.63 \pm 2.85 \mathrm{~mm}^{\mathrm{b}}$ & $187.20 \pm 1.78 \mathrm{~mm}^{\mathrm{b}}$ & $195.37 \pm 1.53 \mathrm{~mm}^{\mathrm{b}}$ & $282.6 \pm 2.32 \mathrm{~mm}^{\mathrm{a}}$ \\
\hline 60 & $47.47 \pm 1.71 \mathrm{~g}^{\mathrm{b}}$ & $55.46 \pm 1.17 \mathrm{~g}^{\mathrm{b}}$ & $58.80 \pm 0.41 \mathrm{~g}^{\mathrm{b}}$ & $193.73 \pm 1.02 \mathrm{~g}^{\mathrm{a}}$ \\
& $174.18 \pm 2.95 \mathrm{~mm}^{\mathrm{b}}$ & $184.70 \pm 184.67 \mathrm{~mm}^{\mathrm{b}}$ & $215.57 \pm 1.84 \mathrm{~mm}^{\mathrm{c}}$ & $279.3 \pm 1.86 \mathrm{~mm}^{\mathrm{a}}$ \\
\hline
\end{tabular}

Table 2. Average values for weight and total length ( \pm SE) of $C$. poeyi juveniles treated with $0,10,20$ and $30 \mathrm{mg}$ of E2 per $\mathrm{kg}$ of food $(\mathrm{n}=60)$ at different days post-treatment $(\mathrm{DPT})$. Survival was $100 \%$ in all treatments. Different letters indicate statistically significant differences $(P<0.05)$.

\begin{tabular}{clccc}
\hline $\begin{array}{c}\text { Treatment } \\
\text { E2 }\left(\mathrm{mg} \mathrm{kg}^{-1}\right)\end{array}$ & \multicolumn{1}{c}{$\begin{array}{c}\text { 0 DPT } \\
\text { mean }( \pm \text { SE })\end{array}$} & $\begin{array}{c}\text { 30 DPT } \\
\text { mean }( \pm \text { SE })\end{array}$ & $\begin{array}{c}\text { 180 DPT } \\
\text { mean }( \pm \text { SE })\end{array}$ & $\begin{array}{c}300 \mathrm{DPT} \\
\text { mean }( \pm \text { SE })\end{array}$ \\
\hline \multirow{2}{*}{0} & $13.06 \pm 0.17 \mathrm{~g}^{\mathrm{a}}$ & $17.19 \pm 0.24 \mathrm{~g}^{\mathrm{a}}$ & $35.13 \pm 1.35 \mathrm{~g}^{\mathrm{a}}$ & $40.02 \pm 1.36 \mathrm{~g}^{\mathrm{a}}$ \\
& $81.79 \pm 1.12 \mathrm{~mm}^{\mathrm{a}}$ & $85.93 \pm 0.96 \mathrm{~mm}^{\mathrm{a}}$ & $189.22 \pm 2.93 \mathrm{~mm}^{\mathrm{a}}$ & $192.11 \pm 5.39 \mathrm{~mm}^{\mathrm{a}}$ \\
\hline \multirow{2}{*}{10} & $13.93 \pm 0.13 \mathrm{~g}^{\mathrm{a}}$ & $18.36 \pm 0.38 \mathrm{~g}^{\mathrm{a}}$ & $44.32 \pm 2.49 \mathrm{~g}^{\mathrm{b}}$ & $48.32 \pm 1.59 \mathrm{~g}^{\mathrm{b}}$ \\
& $91.13 \pm 1.07 \mathrm{~mm}^{\mathrm{b}}$ & $98.12 \pm 1.15 \mathrm{~mm}^{\mathrm{b}}$ & $197.87 \pm 4.59 \mathrm{~mm}^{\mathrm{b}}$ & $209.53 \pm 2.02 \mathrm{~mm}^{\mathrm{b}}$ \\
\hline \multirow{2}{*}{20} & $13.98 \pm 0.12 \mathrm{~g}^{\mathrm{a}}$ & $18.72 \pm 0.40 \mathrm{~g}^{\mathrm{a}}$ & $61.88 \pm 1.53 \mathrm{~g}^{\mathrm{c}}$ & $70.72 \pm 0.89 \mathrm{~g}^{\mathrm{c}}$ \\
& $91.63 \pm 0.95 \mathrm{~mm}^{\mathrm{b}}$ & $99.33 \pm 2.47 \mathrm{~mm}^{\mathrm{b}}$ & $207.00 \pm 4.52 \mathrm{~mm}^{\mathrm{b}}$ & $237.00 \pm 2.35 \mathrm{~mm}^{\mathrm{c}}$ \\
\hline \multirow{2}{*}{30} & $13.86 \pm 0.09 \mathrm{~g}^{\mathrm{a}}$ & $18.47 \pm 0.25 \mathrm{~g}^{\mathrm{a}}$ & $63.37 \pm 0.86 \mathrm{~g}^{\mathrm{c}}$ & $73.59 \pm 1.31 \mathrm{~g}^{\mathrm{c}}$ \\
& $91.83 \pm 0.62 \mathrm{~mm}^{\mathrm{b}}$ & $99.23 \pm 2.45 \mathrm{~mm}^{\mathrm{b}}$ & $211.94 \pm 1.84 \mathrm{~mm}^{\mathrm{c}}$ & $257.50 \pm 2.75 \mathrm{~mm}^{\mathrm{c}}$ \\
\hline
\end{tabular}

resulted in the fastest growth, remaining significant for up to six months; however, all fish reached the same size by the end of the study. Researchs supporting these findings indicate that orally administered E2 has significant growth-promoting effects in fish (Malison et al., 1988; Satoh \& Nimura, 1991; Hiroaki et al., 1993; Blázquez et al., 1998) perhaps because E2 can enhance growth through increased appetite, improved digestion, or increased absorption (Woo et al., 1993). However, contrasting results have been published on the effects of E2 on fish growth; some researchers claim no effects (Matty \& Cheema, 1978; Woo et al., 1993), and others report detrimental effects (Funk et al., 1973; Johnstone et al., 1978; Goetz et al., 1979; Wang et al., 2008). As mentioned above, these effects might be related to the altered interactions between sex steroids and growth hormone, particularly in gonochoric species. Conley \& Walters (1999) highlighted the importance of balance between androgens and estrogens, which is essential for normal sexual development, reproductive function, and normal growth of both sexes in vertebrates. Undoubtedly, the expression and activity of the aromatase enzyme play a fundamental role in maintaining this critical balance. In our study, the survival of $C$. poeyi was not affected by E2 administration, indicating that this protandric species can process up to $60 \mathrm{mg}$ of E2 per kilogram of food with no deleterious effects. Reports indicate that the negative effects of steroid administration on survival depend on some factors, with the most important being treatment timing, treatment intensity, and species (George \& Pandian, 1996).

In the present study, successful feminization and reproductive viability of the females was achieved for the first time in $C$. poeyi. These are major accomplishments for snook aquaculture since females currently used for larval production of large snooks are obtained from wild populations and require between three to four years after confinement to respond to hormonal induction (Ibarra-Castro et al., 2011; Contreras-García et al., 2015). On top of this, broodstock management is also expensive and risky due to the large size of the females. The production of small amounts of larvae from the sex-reversed females (approximately 240,000 per female) provides a practical and manageable solution to handling millions of larvae during every spawning event.

\section{ACKNOWLEDGMENTS}

This research is a component of the AquaFish Innovation Lab, which is supported in part by the US 
Agency for International Development (USAID CA/LWA N ${ }^{\circ}$ EPP-A-00-06-0012-00), and in part by participating institutions. The AquaFish accession number is 1467 . The opinions expressed herein are those of the authors and do not necessarily reflect the views of the AquaFish Innovation Lab or USAID. This study was also partially supported by the Juarez Autonomous University of Tabasco (JAUT) and CONACyT. The authors thank Moisés GonzálezValencia for his technical assistance in the preparation of histological material, Aaron Torrez-Martínez for his outstanding technical assistance in microscopic photography, and Allyse Ferrara for significant editorial improvements.

\section{REFERENCES}

Aguilar, M., Coutiño, B.B. \& Salinas, R.P. 1996. Manual general de técnicas histológicas e histoquímicas. Las Prensas de Ciencias, México D.F.

Alvarez-Lajonchère, L. \& Tsuzuki, M.Y. 2008. A review of methods for Centropomus spp. (snooks) aquaculture and recommendations for the establishment of their culture in Latin America. Aquaculture Research 39(7): 684-700.

Baroiller, J.F., Guiguen, Y. \& Fostier, A. 1999. Endocrine and environmental aspects of sex differentiation in fish. Cellular Molecular Life Sciences, 55: 910-931.

Benton, C.B. \& Berlinsky, D.L. 2006. Induced sex change in black sea bass. Journal of Fish Biology, 69: 14911503.

Beardmore, J.A., Mair, G.C. \& Lewis, R.I. 2001. Monosex male production in finfish as exemplified by tilapia: applications, problems, and prospects. Aquaculture, 197: 283-301.

Blázquez, M., Zanuy, S., Carrillo, M. \& Piferrer, F. 1998. Structural and functional effects of early exposure to estradiol-17 $\beta$ and 17-ethynylestradiol on the gonads of the gonochoristic teleost Dicentrarchus labrax. Fish Physiology and Biochemistry, 18: 37-47.

Carvalho, C.V.A., Passini, G., de Melo Costa, W. \& Cerqueira, V.R. 2014. Feminization and growth of juvenile fat snook Centropomus parallelus fed diets with different concentrations of estradiol-17 $\beta$. Aquaculture International, 22: 1391.

Carvalho, C.V.A., Passini, P., Costa, W.M.C., Vieira, B.N. \& Cerqueira, V.R. 2014. Effect of estradiol-17ß on the sex ratio, growth and survival of juvenile common snook (Centropomus undecimalis). Acta Scientiarum, Animal Sciences, 36(3): 239-245.

Cerqueira, V.R. \& Tsuzuki, M.Y. 2009. A review of spawning induction, larviculture, and juvenile rearing of the fat snook, Centropomus parallelus. Fish Physiology and Biochemistry, 35: 17-28.
Condeça, J.B. \& Canario, A.V. 1999. The effect of estrogen on the gonads and on in vitro conversion of androstenedione to testosterone, 11-ketotestosterone, and estradiol-17 $\beta$ in Sparus aurata (Teleostei, Sparidae). General and Comparative Endocrinology, 1(116): 59-72.

Conley, A.J. \& Walters, K.W. 1999. Aromatization. In: Knobil, E. \& Neill, J.D. (Eds.). Encyclopedia of Reproduction. Vol. 1. Academic Press, New York, pp. 280-291.

Contreras-García, M.D.J., Contreras-Sánchez, W.M., Hernández-Vidal, U. \& McDonal-Vera, A. 2015. Induced spawning of the common snook, Centropomus undecimalis, in captivity using GnRH-a implants. Ecosistemas y Recursos Agropecuarios, 2(6): 357-362.

Chan, S.T.H. \& Yeung, W.S.B. 1983. Sex control and sex reversal in fish under natural conditions. Fish Physiology, 9: 171-222.

Chang, C.F. \& Lee, M.F. 1992. Involvement of estradiol 17 on the processes of natural and control sex reversal in protandrous black porgy (Acanthopagrus schlegeli). Conference presented in Second International Symposium on Fish Endocrinology, Saint Malo, France.

Chávez, H.R. 1961. Estudio de una nueva especie de robalo del Golfo de México y redescripción de Centropomus undecimalis (Bloch). Ciencia, 21(2): 7583.

Chávez, H.R. 1963. Contribución al conocimiento de la biología de los robalos, Chucumite y Constantino (Centropomus undecimalis) del Estado de Veracruz, México. Ciencia, 22(5): 141-161.

Chávez, H.R. 1981. Marcado de robalo prieto, Centropomus poeyi, en la Cuenca del Papaloapan. Ciencia Pesquera, 1(1): 17-26.

Chávez-Caballero, V., Loran-Núñez, R.M., Gómez-Ortiz, M.G., Garduño-Dionate, M. \& Martínez-Isunza, F.R. 2014. Robalo del Golfo de México Centropomus undecimalis, Centropomus poeyi y Centropomus parallelus. In: Beléndez-Moreno, L.F.J., Espino-Barr, E., Galindo-Cortes, G. Gaspar-Dillanes, M.T., Huidobro-Campos, L. \& Morales-Bojórquez, E. (Eds.). Sustentabilidad y pesca responsable en México evaluación y manejo. Instituto Nacional de Pesca, México D.F., pp. 211-241.

De Jesus, E.G., Hirano, T. \& Inui, Y. 1992. Gonadal steroids delay spontaneous flounder metamorphosis and inhibit $\mathrm{T}_{3}$-induced fin ray shortening in vitro (Endocrinology). Zoological Science, 9(3): 633-638.

Devlin, R.H. \& Nagaham, Y. 2002. Sex determination and sex differentiation in fish: an overview of genetic, 
physiological, and environmental influences. Aquaculture, 208: 191-364.

Frisch, A. 2004. Sex-change and gonadal steroids in sequentially-hermaphroditic teleost fish. Reviews in Fish Biology and Fisheries, 14: 481-499.

Flynn, S.R. \& Benfey, T.J. 2007. Effects of dietary estradiol-17 $\beta$ in juvenile shortnose sturgeon (Acipenser brevirostrum), Lesueur. Aquaculture, 270: 405-412.

Funk, J.D., Donaldson, E.M. \& Dye, H.M. 1973. Induction of precocious sexual development in female pink salmon (Oncorhynchus gorbuscha). Canadian Journal of Zoology, 51(5): 493-500.

George, T. \& Pandian, T.J. 1996. Hormonal induction of sex reversal and progeny testing in the zebra cichlid Cichlasoma nigrofasciatum. Journal of Experimental Zoology Part A: Ecological Genetics and Physiology, 275(5): 374-382.

Goetz, F.W., Donaldson, E.M., Hunter, G.A. \& Dye, H.M. 1979. Effects of estradiol-17 $\beta$ and $17 \alpha$-methyltestosterone on gonadal differentiation in the coho salmon, Oncorhynchus kisutch. Aquaculture, 17(4): 267-278.

Goudie, C.A., Redner, B.D., Simco, B.A. \& Davis, K.B. 1983. Feminization of channel catfish by oral administration of steroid sex hormones. Transactions of the American Fisheries Society, 112: 670-672.

Green, B.W., Veverica, K.L. \& Fitzpatrick, M.S. 1997. Fry and fingerling production. In: Egna, H.S. \& Boyd, C.E. (Eds.). Dynamics of pond aquaculture. CRC Press, Florida, pp. 215-243.

Grier, H.J. \& Taylor, R.G. 1998. Testicular maturation and regression in the common snook. Journal of Fish Biology, 53: 521-542.

Grier, H.J. 2000. Ovarian germinal epithelium and folliculogenesis in the common snook (Centropomus undecimalis) (Teleostei: Centropomidae). Journal of Morphology, 234: 265-281.

Hendry, C.I., Martin-Robichaud, D.J. \& Benfey, T.J. 2003. Hormonal sex reversal of Atlantic halibut (Hippoglossus hippoglossus L.). Aquaculture, 219: 769-781.

Hiroaki, C., Kenji, I., Kazuo, H. \& Kohei, Y. 1993. Effects of dietary estradiol-17 $\beta$ on feminization, growth and body composition in the Japanese eel (Anguilla japonica). Comparative Biochemistry and Physiology Part A: Physiology, 106(2): 367-371.

Huber, C.G., Grabowski, T.B., Pope, K.L. \& Patiño, R. 2014. Distribution and habitat associations of juvenile common snook in the lower Rio Grande, Texas. Marine and Coastal Fisheries: Dynamics, Management and Ecosystem Science, 6: 170-180.
Hunter, G. \& Donalson, E. 1983. Hormonal sex control and its application to fish culture. In: Hoar, W.S. \& Donalson, E.M. (Eds.). Fish physiology and reproduction. Academic Press, New York, pp. 223304.

Ibarra-Castro, L., Alvarez-Lajonchère, L., Rosas, C., Palomino-Albarrán, I.G., Holt, G.J. \& SánchezZamora, A. 2011. GnRHa-induced spawning with natural fertilization and pilot-scale juvenile mass production of common snook, Centropomus undecimalis (Bloch, 1792). Aquaculture, 319(3): 479-483.

Islinger, M., Wilimsky, D., Völkl, A. \& Braunbeck, T. 2003. Effects of $17 \alpha$-ethynilestradiol on the expression of three estrogen-responsive genes and cellular ultrastructure of liver and testes in male zebrafish. Aquatic Toxicology, 62: 85-103.

Johnstone, R., Simpson, T.H. \& Youngson, A.F. 1978. Sex reversal in salmonid culture. Aquaculture, 13: 115-134.

Kim, D.S., Nam, Y.K. \& Jo, J.Y. 1997. Effect of oestradiol-17 $\beta$ immersion treatments on sex reversal of mud loach, Misgurnus mizolepis (Günther). Aquaculture Research, 28(12): 941-946.

Kuo, C.M., Ting, Y.Y. \& Yeh, S.L. 1988. Induced sex reversal and spawning of blue-spotted grouper, Epinephelus fario. Aquaculture, 74(1-2): 113-126.

Lin, H.R., Lu, M., Lin, X.W., Zhang, W.M., Sun, Y. \& Chen, L.X. 1995. Effects of gonadotropin-releasing hormone $(\mathrm{GnRH})$ analogs and sex steroids on growth hormone $(\mathrm{GH})$ secretion and growth in common carp (Cyprinus carpio) and grass carp (Ctenopharyngodon idellus). Aquaculture, 135(1-3): 173-184.

Loran-Núñez, R.M., Martínez-Isunza, F., ValdezGuzmán, A.J., Garduño-Dionate, M. \& MartínezLoran, E.R. 2012. Reproducción y madurez sexual de robalo prieto (Centropomus poeyi) y robalo blanco $(C$. undecimalis) en el Sistema Lagunar de Alvarado, Veracruz (2005-2007). Ciencia Pesquera, 20(1): 4964.

Malison, J.A., Kayes, T.B., Wentworth, B.C. \& Amundson, C.H. 1988. Growth and feeding responses of male versus female yellow perch (Percaflavescens) treated with estradiol-17 $\beta$. Canadian Journal of Fisheries and Aquatic Sciences, 45(11): 1942-1948.

Matty, A.J. \& Cheema, I.R. 1978. The effect of some steroid hormones on the growth and protein metabolism of rainbow trout. Aquaculture, 14(2): 163-178.

Meijide, F.J., Lo Nostro, F.L. \& Guerrero, G.A. 2005. Gonadal development and sex differentiation in the cichlid fish Cichlasoma dimerus (Teleostei, Perciforms): a light- and electron-microscopic study. Journal of Morphology, 264: 191-210.

Nakamura, M. 1984. Effects of estradiol-17 $\beta$ on gonadal sex differentiation in two species of salmonids, the 
masu salmon, Oncorhynchus masou, and the chum salmon, O. keta. Aquaculture, 43: 83-90.

Nakamura, M. \& Takahashi, H. 1973. Gonadal sex differentiation in tilapia mossambica with special regard to the time of estrogen treatment effective in inducing feminization of genetic fishes. Bulletin of the Faculty of Fisheries, Hokkaido University, 24: 1-13

Nakamura, M., Kobayashi, T., Chang, X.T. \& Nagahama, Y. 1998. Gonadal sex differentiation in teleost fish. Journal of Experimental Zoology, 281: 362-372.

Nozu, R., Kojima, Y. \& Nakamura, M. 2009. Short term treatment with aromatase inhibitor induces sex change in the protogynous wrasse, Halichoeres trimaculatus. General and Comparative Endocrinology, 161(3): 360-364.

Omoto, N., Maebayashi, M., Mitsuhashi, E., Yoshitomi, K., Adachi, S. \& Yamauchi, K. 2002. Effects of estradiol-17- $\beta$ and 17- $\alpha$ methyltestosterone sex differentiation in F2 hybrid sturgeon. Fisheries Science, 68: 1047-1054.

Pandian, T.J. \& Sheela, S.G. 1995. Hormonal induction of sex reversal in fish. Aquaculture, 138: 1-22.

Passini, G., Vaz Avelar, C.C., Carneiro, S.F. \& RonzaniCerqueira, C. 2016. Induction of sex inversion in common snook (Centropomus undecimalis) males, using $17 \beta$ oestradiol implants. Aquaculture Research, 47: 1090-1099.

Patiño, R. 1997. Manipulations of the reproductive system of fishes by means of exogenous chemicals. The Progressive Fish Culturist, 59: 119-127.

Piferrer, F. 2001. Endocrine sex control strategies for the feminization of teleost fish. Aquaculture, 197: 229281.

Popma, J.T. \& Green, W. 1990. Sex reversal of tilapia in earthen ponds. Research and Development Series, 35: 1-15.

Saillant, E., A. Fostier, B. Menu, P. Haffray \& B. Chatain. 2001. Sexual growth dimorphism in sea bass Dicentrarchus labrax. Aquaculture, 202: 371-387.

Satoh, H. \& Nimura, Y. 1991. Growth promotion in Japanese eel by the oral administration of an estrogen (diethylstilbestrol). Nippon Suisan Gakkaishi, 57: 2127.

Secretaría de Agricultura, Ganadería, Desarrollo Rural y Alimentación (SAGARPA). 2017. Información estadística por especie y entidad. Secretaría de Agricultura, Ganadería, Desarrollo Rural y Alimentación. [http://www.conapesca.gob.mx/wb/cona/informacion _estadistica_por_especie_y_entidad]. Reviewed: 10 January 2018.
Silva, C.P., Otero, M. \& Esteves, V. 2012. Processes for the elimination of estrogenic steroid hormones from water: a review. Environmental Pollution, 165: 38-58.

Strüssmann, C.A. \& Nakamura, M. 2002. Morphology, endocrinology, and environmental modulation of gonadal sex differentiation in teleost fishes. Physiology and Biochemistry, 26: 13-29.

Strüssmann, C.A., Takashima, F. \& Toda, K. 1996. Sex differentiation and hormonal feminization in pejerrey (Odontesthes bonaeriensis). Aquaculture, 139: 31-45.

Taylor R.G., Whittington, J.A., Grier, H.J. \& Crabtree, R.E. 2000. Age, growth, maturation, and protandric sex reversal in common snook, Centropomus undecimalis, from the east and west coasts of South Florida. Fishery Bulletin, 98: 612-624.

Tucker, J.W. 2003. Snook culture. World Aquaculture Society Magazine, 34(4): 42-46.

Food and Agriculture Organization (FAO). 2011. Review of the state of world marine fishery resources. FAO Fisheries and Aquaculture Technical Paper №569, Rome. http://firms.fao.org/firms/resource/11842/en. Reviewed: 13 January 2018.

Vidal-López, J.M., Álvarez-González, C.A., ContrerasSánchez, W.M., Patiño, R., Hernández-Franyutti A.A., Hernández-Vidal, U. \& Martínez-García, R. 2012. Feminización de juveniles del robalo blanco Centropomus undecimalis (Bloch 1792) usando 17- $\beta$ estradiol. Revista de Ciencias Marinas y Costeras, 4: 83-93.

Wang, H.P., Gao, Z., Beres, B., Ottobre, J., Wallat, G., Tiu, L. \& Yao, H. 2008. Effects of estradiol-17ß on survival, growth performance, sex reversal and gonadal structure of bluegill sunfish Lepomis macrochirus. Aquaculture, 285(1): 216-223.

Woo, N.Y.S., Chung, A.S.B. \& Ng, T.B. 1993. Influence of oral administration of estradiol- $17 \beta$ and testosterone on growth, digestion, food conversion and metabolism in the underyearling red sea bream, Chrysophrys major. Fish Physiology and Biochemistry, 10(5): 377387.

Yanes-Roca, C., Rhody, N., Nystrom, M. \& Main, K.L. 2009. Effects of fatty acid composition and spawning season patterns on egg quality and larval survival in common snook (Centropomus undecimalis). Aquaculture, 287: 335-340.

Zarza, E.A., Berruecos, J.M., Vázquez, C. \& Álvarez, P. 2006. Cultivo experimental de robalo Centropomus undecimalis (Bloch, 1792) y chucumite Centropomus parallelus (Poey, 1860) (Perciformes: Centropomidae) en agua dulce en un estanque de concreto en Alvarado, Veracruz, México. Veterinaria Mexicana, 37(3): 327333. 